in: Anthony, Francis-Vincent / Hans-Georg Ziebertz (Hg.): Religious Identity and National Heritage. Empirical Theological Perspectives. Brill 2012, S. 73-90

\title{
The Relation of Religious Identity and National Heritage among Young Muslims in Germany
}

\section{Christel Gärtner / Zehra Ergi}

Religious identity was weakened in the 1960s due to decisive changes in the religious history of the Western World as well as the push of secularization (cf. Lehmann 2004; McLeod 2007). It is no longer a shared core of the structure of identity in western-European societies. Based on their secularised self-perception, host societies expect migrants to integrate by giving up their religious bonds or to only express them in their private lives (cf. Reuter 2009, 188). Even though migrants often keep up their religious bonds and practices (they frequently use religious networks to settle down in the host country, but they also maintain contact to their home country in case the migration fails), the circumstances in the process of migration and demands in a new culture inevitably reshape religious beliefs and practices (cf. Ammerman 2003, 208; Levitt/Jaworsky 2007; Levitt 2009).

In our essay, we will focus on young Muslims with a Turkish origin who were born and raised in Germany. Religion and national heritage remains an important component of identity for both migrants and also their children. This differentiates the young Muslims from their German, mostly Christian-secularized, peers, for whom religion does not play an important part in their lives, whereas the majority of the Muslim youth in Germany think of themselves as religious. For this second generation, the religious field is already restructured through their parents' migration (cf. Reuter 2009). Another difference between the autochthonous youth and the young Muslims is that they grow up with, or between, two cultures: the Islamicnational culture of their family's origin and the German secularized culture. It is those borders between the two cultures which become blurred depending on the milieu and regional context in which the individual lives. This occurs because the ethnic communities in which second generation migrants grow up are themselves embedded in the host society, and because they (the second generation migrants) have to begin participating in it starting with the first day of school. That way the host culture becomes a point of reference for the development of the child's identity. At the latest during adolescence young Muslims have to position themselves within these two cultures and integrate them into their identity - this leads to a continuation and a continuous transformation of both cultures.

This process of reproduction and transformation - on the micro-level - is the focus of our essay. We will explore how important religion is for young Muslims in their formative phase, and how the experience of being part of a minority influences the formation of their identity. First, we will discuss the concept of identity which we refer to in this essay (1). Then we will detail our concept of religion, and shortly remark on our methodical approach (2). Finally we will analyse two contrasting case studies of young female Muslims and show how these 
young women generate their identity in the triangle of their ancestral environment, their peers and the host culture. We will particularly elucidate how these young female Muslims deal with and integrate religion and cultural heritage into their identity (3).

\section{Concept of identity formation: processes of socialization between ancestral environment, peers and receiving culture}

Recently, there has been discussion within the field of sociology as to whether, due to the increasing fragmentation of daily life, coherent identity structures can still exist in modern, functional differentiated societies (cf. Giddens 1991, Ammerman 2003; Modood 2003; Herbert/Ziebertz 2010). It is, however, disputable if modern identities still include "elements of continuity (being the same person over time), integration (being a whole person, not fragments), identification (being like others), and differentiation (being unique and bounded)" (Ammerman 2003, 209). In order to understand how and if individuals generate a certain coherence parallel to the complexity of their identity structures, we need concepts which account for constantly transforming borders as well as the persistence of sociality and tradition: "Neither selves nor groups are utterly reconstituted with each new encounter. Some continuity clearly prevails at the same time that a complex society continually challenges that continuity" (Ammerman 2003, 211). We agree with Giddens insofar as that the "reflexive project of the self $[\ldots]$ consists in the sustaining of coherent, yet continuously revised, biographical narratives" (Giddens 1991, 5).

We primarily refer to George Herbert Mead's theory of the self (Mead 1962) which we amend with Oevermann's interpretation of Mead (Oevermann 1991), according to which identity always takes place in the limits of historic and social spaces. This setting provides a frame of objective possibilities, which become reality through individual choice and the justification thereof. Therefore there must be a difference, for example, between being a daughter, Muslim, adolescent, student in Turkey or in Germany. We emphasise Mead's point of view that because of their embedment in sociality individuals are socially recognised from their birth on. This we connect to Bourdieu's concept of the habitus (Bourdieu 1974, 1976). We place emphasis on the habitus being a structure which allows individuals to be part of the social practice and enables them not only to generate but also to change these practices. Children acquire the habitus by taking part in their family's day-to-day life and in concrete social environments; in our cases that means the Turkish-Islamic community which itself is embedded in historic and social space of the host society. The habitus defines and structures the individual's lifestyle and opportunities in life, their identity (for example, man or woman, car mechanic or doctor) as well as their attitudes towards the world. This said, the habitus is not to be understood as a static structure; according to Bourdieu the early habitus will in fact be reconstructed and overlaid by newer ones, but it will never be wholly erased. An example of this is that Muslims continue to avoid eating pork even when they are no longer religious. The habitus which was acquired in the family environment underlies experiences at school and will be transformed through the school experience. This transformed habitus will yet 
again structure later experiences (Bourdieu 1976, 188), for example the professional socialization.

According to Mead, identity is essentially a social structure, which arises from social experience. In the process of socialization individuals adopt the everyday, religious and political world views, norms, values, and interpretive framework of their environment. These are gained heteronom, and become natural components of identity, so to speak. For Muslim youths with a Turkish origin it means that they will acquire the competence "to manage several cultural repertoires at once and to access social networks in several contexts [...]. Children apply these values and social contracts at school, at work or at the church or mosque" (Levitt 2009, 1226). The ethnic community generates social networks, which open new possibilities as well as inducing social bonds and limiting liabilities.

In general, patterns of identity are taken for granted, and will not be reflected until the phase of adolescence. It is important to keep in mind, that during this phase of forming one's identity that the existing structures will be blurred and therefore can be reshaped (Erikson 1970; Erdheim 1983; Blos 1995). In this ontological period, the infantile attachment to the parents has to be given up in favour of an independent identity, so that individuals can find their position in society. In addition, individuals are confronted with the problem of probation, a task which has to be solved autonomously for the first time (Gärtner 2003, 104). This means that adolescents have to position themselves towards certain themes or ideals, such as religion, in order to find and form their own identity. We will return to this concept later.

Generally, the adolescent processes of forming one's identity take place between the family homes, peers and the surrounding society. These processes prove to be more complex for children of migrant than for their autochthon peers. Scholars of a transnational approach claim that "the second generation is situated between a variety of different and often competing generational, ideological and moral reference points, including those of their parents, their grandparents and their own real and imagined perspectives about their multiple homelands" (Levitt 2009, 1238). The way Muslim youths cope with these adolescent processes and the way in which they generate a fitting script for their future mainly depends on their family homes as well as to what extend the Turkish-Islamic communities and the German host society provides them a psychosocial moratorium (Erikson 1970) in which they have the possibility to experiment and are allowed or even encouraged to take the necessary steps for integration and development (King 2002).

Children of Muslim migrants already experience being different at school - they are considered as national, religious, ethnic and cultural different (Herbert/Ziebertz 2010). In addition, the confrontation with the interpretive framework and scripts of the social majority as the "significant other" (Schiffauer 2002, 55), as well as the challenge thereof becomes important at the latest during adolescence, when the individuals have to grapple with it on their own. Subsequently, we will reconstruct how the adolescents experience and 
communicate the connected struggles of acceptance, which are being fought out in the conflict between similarity and difference.

\section{The problem of probation as the structural core of religion}

We will now return to the problem of probation. Why and how is it relevant in the crisis of adolescence? We will connect this question to a theoretical concept of religiousness which is related to the analysis of our case studies.

According to the German sociologist Ulrich Oevermann, religiousness is a universal feature of human life (cf. Oevermann 1995, 2003). Oevermann further states that it emerges as a specific human structure at the point at which the individual becomes aware of the finite nature of life, and, in addition, realises that the future is - hypothetically - open. This realisation sets in motion an unstoppable dynamic: individuals have to make decisions without knowing if these decisions are the correct, adequate or valid ones. This is the motivation behind seeking out "myths of probation" - as Oevermann calls it - which hold hope of a satisfying life and provide a provisional answer to the main existential questions of human life, which are: "Where do I come from?", "Where am I going to?", and, "Who am I?" Religion has been providing answers to these questions for a long time, and continues to do so today. However, the more secularised a life practice is, the more individualised the answers have to be since they have become the criterion for a person's successful conduct through his or her life.

The answers, religious or non-religious, are valid as far as they are applicable to an individual life and at the same time are shared by a community. Due to this concept adolescence is defined as an ontological period during which young people are confronted with the crises mentioned above. They have to find serious answers to questions that help them to position themselves in terms of what they want to achieve as an individual, for example, their professional and family ambitions, how they want to engage themselves in their community, and how they wish to fill their position as a citizen.

Beside this structural concept of religion, which understands the problem of probation as a universal problem in the human conduct of life, we also refer to religion as a discursive fact (cf. Matthes 1992). Therefore, we do not define religion ex ante, but instead reconstruct what Muslim youth depict as religious and which role religion plays (for them) particularly in regard to how they conduct their lives. This means: "Describing religious identities is not a matter of asking a checklist of categorical questions, but a matter of analyzing a dynamic process" (Ammerman 2003, 224). This process takes place in social interactions (cf. Ziebertz/Hermans et al. 2010, 88) in which the religious identity is orally negotiated referring to the national-cultural heritage as well as the demands of the receiving society.

In the following, we will discuss two contrasting case studies, which we analysed using the method of objective hermeneutics (cf. Oevermann 2000, Jindra/Jindra 2003). Using the collected data material and interviews from these two case studies we will trace the 
embedment in different social environments (such as family, class or rather milieu, historic situation) on the basis of the biographical data, and sketch out our first hypotheses. Furthermore, we will reconstruct in which ways the structures of the family environment are reproduced and transformed. Through doing so, we will elucidate the characteristics and distinctive features of these cases.

\section{Case Studies}

The cases deal with two young, Muslim women: Celile, born in 1990 and 20 years old at the time of the interview, and Berna, born in 1988 and 17 years old at the time; both were born in Germany. They have a comparable course of education, as they both attended Gymnasium (upper secondary school) and plan to go to university. Religious tradition is also a part of the family background for both. Celile's maternal grandparents and great-grandparents are Sunni religious teachers, called khojas. Her mother continues the tradition in Germany as a khoja. Berna's grandfather is a dede, the religious head of an Alevi community. This position is passed from father to son. It is also passed to Berna's father, but he breaks from the family tradition and becomes an atheist. Due to her family's Kurdish and Alevi roots, Berna's family belongs to two minority groups in Turkey. Celile's family, however, is among the SunniTurkish majority.

The reconstruction of the cases that we present follows a line of questioning that asks about Muslim youths' conceptualization and formation of identity based on their relationships to their background milieu, their peers, and society as composed by the German majority ("host society"). Taking this as our point of departure, we would like to discuss three dimensions as they relate to both cases: the influence of background milieu on identity formation for youths; their experience of difference and how they deal with it in their interactions with the host society; and their career plans. In the course of discussing these three dimensions, we will work out how the embrace of religion plays a role in adolescents' attempts to deal with questions of identity. In Celile's case, we will look at her decision to wear a headscarf in order to show this dynamic. For Berna, we will examine her position towards pre-marital sex within this context.

\subsection{Celile}

At the age of 16, Celile's parents (the father in 1982, the mother in 1986) migrate from the same province in the Northeast of Turkey to join their families, who are already residing in Germany. They live in the Ruhr region, which has a large foreign, especially Turkish, population. Since the parents leave their country of origin as adolescents, we can presume that they have already interiorized Turkish values and norms. These values and norms continue to be maintained through their move into an area marked by Turkish influence. The choice of partners between the parents also shows a preference towards that which is already familiar: their choice does not include partners from the entire Turkish community, but rather it is limited to people who share their same regional culture. 
The parents marry when Celile's father is 21 and her mother is 17 . What would have been considered an early marriage in Germany in the 1980s is a reproduction of common practices in Turkish culture. The early marriage and starting a family at a young age imply that the parents are not using migration to increase personal advantages, for example, by pursuing educational advancement first and then marrying later. Quite possibly such a life plan lies beyond the horizon of possibilities for their specific milieu or culture. Still, advancement goals are apparent in the father's professional trajectory from laborer to foreman. The mother's volunteer work as a religion teacher in the mosque also reflects a similar focus on advancement.

Celile's embeddedness within the regional Turkish culture of her parents can have a limiting effect on her life script. For example, her embedment can promote the reproduction of traditional gender roles or marrying early and starting a family. On the other hand, Celile and her siblings are on an educational path that indicates that there is already a transformation of cultural patterns taking place in the family: Celile and her older sister (as well as her two younger brothers) attend Gymnasium. By now, her sister is at university, and Celile is waiting for an opening at a university to study medicine. From this data, it follows that the parents do not expect that their daughters marry young, thereby renouncing an expectation that would otherwise maintain their tradition. Instead, the marriage age for Celile and her sister is postponed due to taking advantage of educational opportunities and pursuing career advancement. Other research has claimed that goals for advancement among migrants generally appear as a task that the parents set for their children in order to compensate for their own (low) status (cf. Levitt 2009, 1230) and to contribute to the success of the overall project of migration (cf. Apitzsch 2005, 13). However, the mobility and educational aspirations that parents promote open real opportunities for youths to integrate into the host society. Apparently, parents accept the risk that their children might become estranged from their milieu through advancement. By completing her Abitur (A-levels), Celile increases her chances to attain social and economical advancement through professional achievement, thereby also enabling her successful integration into the job market of the host society.

Beyond opening possibilities for participating in education, Celile's parents are also paving the way for political participation in the host society for their children. In 2000, they claim German citizenship. The decision reflects a clear sense of being settled in Germany and a positive position towards the German judicial and national system. Even within a homogenous Turkish milieu, Celile's socialization is still connected to the host society through her parents' emphasis on career and citizenship.

Celile likely becomes acquainted with the attitudes of the German host society towards migrants and their children through her milieu, the earliest source for such information. She is still a child when the debates take place concerning the reform of citizenship laws (in 1999, an easing of naturalization requirements and reduced acceptance of multiple citizenship) and so called German "Leitkultur" (in 2000). After the September 11th terror attacks in 2001, the social discourse shifts however towards a polemic awareness of Islam. At this time, migrants 
stop being referred to based on their nationality (as "Turks"), but rather based on their religious affiliation (as "Muslims") (cf. Tiesler 2006). We presume that Celile is confronted with this negative discourse on Islam when she enters adolescence and thereafter has to take a position on it.

In the following we will reconstruct and evaluate Celile's case for its case-specific particularities with regard to our central line of questioning. To what extent do the hypotheses concerning her socio-cultural embedding hold as formulated above? It is important to keep in mind with this reconstruction that the particularity of Celile's case (a particularity that she herself gives shape to through language) is based upon the aforementioned biographical experiences. No implication of an already completed process of identity formation is intended in our analysis.

We begin with Celile's first statement in response to the opening question of the interview. The question asks about how the transition into adult life is shaping up for her and how she makes decisions that impact her future.

C: [...] of course family is an important influence also [...] families always have certain principles that you pretty much have to accept [...] and anyways I'm also influenced by my surroundings. It's only after I check out what my family thinks about my decision and [what] other people around me think about it. Then I make a decision [...] but only once everybody is okay with it [...] that way I can live peacefully.

Celile discusses her adolescence as shaped by the influence of her family and surroundings, which indicates the limitations that her milieu imposes upon her. Another model also applies to her case implicitly, one that does not include this limitation. That model is based on the call for youths in modernized societies to individualize and be innovative with trying out various life plans. By emphasizing the limits placed on her freedom to make decisions, Celile introduces a difference between her and her German friends, who represent an important point of reference for her.

From this it is possible to develop the hypothesis that the different, possible schemas that Celile can try out, beyond those included in the "principles" particular to her milieu, are themselves limited. It is evident from her statement that she shows little willingness to enter into conflicts, which would actually allow for negotiating new boundaries.

At the very latest, Celile enters into the German host society by the time of her enrolment in school. In school, she finds out that her German teachers and schoolmates belong to another religion, namely Christianity. This difference is of little consequence for Celile initially. But she later has the positive experience of finding out that this difference need not be something divisive:

C: We were sitting at a table where people were eating pork and we were eating something else but we were all happy. 
In a certain respect Celile's description is a utopian vision that includes the possibility of a community with coexisting differences. That implies that she would be recognized as an equal with her own particular differences. She has such experiences whenever her achievements in school are valorized and, at the same time, her cultural background does not play a part in that recognition. These experiences initially confirm Celile's utopian vision, which is disrupted when she begins to wear a headscarf at age twelve (we will address this again later), as people stop acknowledging her as an equal despite differences:

C: Because lots of people told me, my German friends, teachers [...] Hey, look! You're totally being oppressed. And I was like, why's that? You're really smart [...] but when it comes to religion your totally dumb. You're totally letting yourself be oppressed, they'd tell me.

The important people in Celile's class at school, who serve as points of reference, confront her concerning the headscarf with a pattern of interpretation that belongs to the German host society. In their responses to the headscarf, they bring up implicitly the asymmetrical gender relations and the backwardness of Islam, alongside the argument about oppression. In other studies on Muslim migrant youth it has come to light that the polemicizing, or rather politicizing way that teachers deal with the issue of the headscarf is not a singular, individual occurrence. This attitude includes (in a broader context) the supposed non-constitutionality of wearing the headscarf (cf. Mannitz 2006, 143 pp.; Schiffauer 2002, pp. 58-67) Indeed, their attitudes express a common stereotype. Accordingly, Celile's headscarf is not interpreted as an expression of her own volition. There is no justifiable reason she could give that would be satisfying, and they are not interested in her motivations. Thus, Celile finds out that her uniqueness is not always accepted; she is excluded due to her difference.

The exclusion becomes more acute for Celile when she is denied a training position as a doctor's assistant due to her headscarf. Her appointment as a trainee depends upon her not wearing the headscarf. Discrimination comes to have concrete consequences, since the circumstances bar Celile from real possibilities. To start, she is excluded from sectors of the German job market. Furthermore, the only option left for her is to study, even though she has cultivated the view that she might better be able to combine family and career with a training program. Thus, the moment for Celile to marry or start a family gets pushed back until sometime after her studies. Right during her transition into professional life, Celile is reduced to an ostensibly typical characteristic for someone with her cultural background, even though she is doubly qualified, namely through her high grades on her Abitur and her time spent doing an internship in the field of medicine. One can conclude from this that, from her perspective, her efforts towards advancement through education, training, and accomplishments are not sufficiently appreciated. Celile reacts to this experience with a lot of resentment and a defiant attitude: she declines the offer to remove her headscarf and renounces the training program. Her personal explanation for doing so is that God's word counts more than man's. 
Our thesis is that Celile cannot simply remove her headscarf when a situation demands it because it has become an integral part of her identity. This thesis is proven through Celile telling about how she started wearing the headscarf in the sixth grade after her best friend started wearing it. Together they go through religious socialization with visits to the mosque and take on the patterns of their milieu, where wearing a headscarf goes without saying. Celile communicates to her parents her desire to wear a headscarf when she is just eleven years old.

C: and my parents didn't like it and they didn't want me to wear a headscarf so early. They told me to take time to think it over [...] if you do something then you need to stand behind it. You need to know what you're doing. Then they gave me time.

We can derive the following hypotheses from Celile's portrayal of the negotiation process with her parents: Her parents do not force Celile to wear the headscarf; it is her own initiative. Celile's latent wish finds expression in her later reconstruction of the situation, namely that the option of wearing the headscarf later was not only something that her parents would have suggested, but that they would have even given her the option not to have to wear it at all. Her ambivalent statements about 'taking her time' and 'giving it time' indicate as much. Celile's decision to start wearing the headscarf in the sixth grade becomes a heavy burden to bear in light of her current experiences of discrimination, exclusion, and disadvantage. The consistency that her parents demanded, which Celile internalized, along with the rejection she experienced by the host society contribute to her resolution to stick with her decision. For, from Celile's point of view, now the decision really has to prove to be the right one. Renouncing the headscarf would be a failure in the eyes of her parents and her milieu. Furthermore, Celile would consider it a sign of subjugation to the host society. On the other hand, Celile also has to realize that what would be a natural and logical decision for her (and her milieu) would be met with hostility from the German host society. It follows that Celile's utopian vision, in which one is acknowledged as different and yet is still treated as an equal, falls apart. Moreover, Celile's real exclusion from sectors of the German job market tarnishes the options within the host society that are open to her given her socialization. This leads Celile to state bitterly:

C: we're neither Turks nor Germans we are we don't even know what we are ourselves

This statement can be interpreted as an expression of an acute crisis: Celile dramatically expresses her experience of disintegration. According to our concluding hypothesis, Celile's commitment to the Islamic faith and her continuative practice of wearing the headscarf become more important with the denial of any national belonging. Her faith provides her with an unconditional recognition of her cultural peculiarity.

\subsection{Berna}


In our treatment of the second case we will similarly begin with Berna's socio-cultural embedding in her milieu and the German host society. Then we will show the specificity of her case, as reconstructed through our interview analysis, with attention to our central line of questioning. We will also highlight the commonalities and differences between Berna's case and Celile's.

Berna's parents come from a province in eastern Anatolia. They are Alevi Kurds. In 1978, at the age of 18, her father goes to Germany to study in the Rhein-Main region, where his father and older brother are already employed as guest workers. Her mother migrates in 1976 at the age of 12 and joins her family, already living in the Ruhr. Both families came to Germany as part of the recruitment of guest workers. After completing his studies in the humanities, Berna's father goes on to train as an interpreter. Her mother works, but has not learned a trade or profession. They marry at the ages of 26 (the father) and 22 (the mother).

One can conclude from the biographical information on Berna's parents that they are carrying out a transformation of traditional and cultural patterns within their generation, which contrasts with Celile's parents. Berna's father does not come to Germany as a guest worker, like his father and brother before him, but rather he comes to study. His studies push back the time for marrying and starting a family; the number of children (Berna has one younger brother) indicates a common family size for western societies, which contrasts to the parent's family background (the father has six siblings; the mother has four). Our claim is supported by the fact that Berna's father does not perpetuate his religious heritage as dede; instead, by going to the university, he turns towards the secular tradition of knowledge and thinks of himself as an atheist. Her mother's gainful employment indicates a change in cultural patterns, for example, the traditional division of labor between the sexes. Since Berna's parents do not practice Alevism, she grows up without religious socialization.

Although they have put into practice a modern lifestyle, Berna's parents seek a spouse who comes from the same province as they do, just like Celile's parents. Regional Alevi cultural values and norms are, therefore, important for them and are secured through their marriage. In terms of Berna's socialization, this means that, in one regard, she internalizes the KurdishTurkish and Alevi value system that her parents expose her to through practical day-to-day living. In another regard, she becomes familiar with the German host society's conception of life through her father's education and her mother's employment. The presence of two cultural systems expands Berna's scope of action. In addition, an academic career is already an option of Berna because of her father. Attending university would not create distance between her and her milieu, as it would for Celile. This finds expression in Berna's high achievement at Gymnasium and in her plans to study in the field of economics, which is part of her vision of the future.

Given their Alevi-Kurdish background, the parents belong to a double minority in Turkey, whose political and cultural repression is first publicly thematized in the 1980s. The Kurdish Labor Party (PKK) begins an armed battle against the Turkish state in 1984. In 1989, the Alevi organize themselves with the publication of the "Alevi Manifesto" in Hamburg (cf. 
Kaya 2009, 60). While apprehension dominates the attitudes in Turkish society towards this newly awoken ethnic consciousness, Alevi and Kurds abroad in Europe (in Germany as well), experience support and solidarity.

In terms of Berna's development, one can form a hypothesis based on this information that, if she professes Alevi faith or her Kurdish background, she will no longer have to hide her Alevi-Kurdish roots, like the generation before her (cf. Kaya 2009, 59). She will not experience discrimination due to her background, but, quite the opposite, she can rely upon the political reverence of her minority status in Germany. In turn, this means that she might find herself on the side of the German host society when it comes to the negative discourse against Islam. For this discourse is directed mostly at Sunni Turks (along with other nationalities), rather than at the Alevi or Kurds.

Now we would like to turn to the interview conducted with Berna. The reconstruction shows that, as in Celile's case, the parent's influence on how Berna shapes her adolescence is significant. This is clear from the very beginning of the interview, when Berna responds to a question about how she copes with the tasks that lie before her at her age:

B: Right now sure, of course, I have a lot of contact with my parents and stuff and sure they tell me that such and such is right and that when you do such and such this way or that and that you should do it this way. And sure however they say to do it, I'll try to really do it

In contrast to Celile, Berna discusses her parents' influence on her life as something positive. She does not experience her parents as setting boundaries, but rather as providing orientation. It is implicit in Berna's formulation that she perceives a lot of options available to her. Thus, she often follows her parents' advice, which for her also includes normative guidelines, but she can also make a decision that is contrary to their wishes, for example, when it is something important to her like picking a course of study. While Celile experiences her family's principles as a limitation (her socialization makes her subject to her parents' principles in the first place), Berna perceives parental advice as backing and support in the process of positioning herself in adolescence. Berna, like Celile, expresses a desire to live in accordance with her parents' guidelines. However, she does not experience this as an absolutely binding relation, as Celile does. Celile believes that she must maintain those principles specific to her milieu in order to even stay part of the community.

We conclude from this fundamental difference between the two young women that Berna is aware of not only the diversity in her scope of action, but also the uncertainties connected with that. She is thus receptive to and thankful for parental guidance. For Celile, however, the experience of being limited obviously prevails - aggravated by the discrimination she experienced - since the experience entails closing off options for her.

Still, Berna and Celile share the fact that they both experience their differences from the German youths at the onset, or during, puberty, when one's own sexuality becomes an issue: Celile's headscarf indicates the transition from being a child to becoming a woman. It, 
thereby, also indicates the possibility of sexual experiences, which according to Islamic views should only occur once married. Even though Berna does not wear a headscarf (wearing them is not a practice among Alevi women), she too has internalized the virginity norm (cf. Ziebertz/Caster/Betz 2010, 218):

B: now if we Turkish girls now say that we can't have a boyfriend before marriage that's 'cause - yeah, why is that - that's just not human. It's completely normal to have a boyfriend, but in our culture that's just not how it is, and even if I'm living here, I'm still goin' to hold on to my culture

We form the following suppositions based on Berna's statement: Berna internalized the virginity norm as a cultural guideline and not as a religious one. This is implicit in her mention of the "Turkish girls" (for Berna, Turkish culture holds a more prominent and generalized position than her particular Kurdish culture, which acts as a subset of Turkish culture). Since sexual relationships become possible with entry into adolescence, the topic of "going out and meeting boys" also becomes relevant. In this phase, she realizes that she differs from her German girlfriends with regard to this concern. They see premarital sexual relationships as a matter of course. At the same time, she recognizes that they have options available to them that remain barred to her. We assume that this first significant experience of difference leads Berna to question her identity and roots, questions that are constitutive for the formative phase of adolescence. As she portrays it, Berna's turn towards Alevism was preceded by a period in which she felt at home in western/American pop culture, just like her German peers. The change in Berna's assessment of her cultural background begins when she is about 15 years old, thus, by an age when differences between her and her German girlfriends must already have been an issue. She says:

B: and then, yeah, after a while, um, yeah, I don't know [...] I just somehow liked Turkish music better. Then I started up with folklore and all and started goin' to all those Turkish associations. And I was just interested in all those things

Berna's cultural background also opens up membership to new communities for her. Her difference, thus, has a positive flipside that is full of vivacity and opens up further options. For example, she can have a conversation about possible courses of study directly with the university students in her folklore group. Celile's difference, however, leads to exclusion and painful experiences that as a whole narrow her scope of action. Furthermore, Berna attends meetings at Alevi associations and takes part in Alevi religious services, where she also practices Alevi religious dances. These religious services are special in that they are simultaneously an expression of Alevi culture. Their main feature is religious songs that are mostly sung in Turkish. This means that Berna's turn towards Alevi culture is also a turn towards Alevi religion. Her participation in the religious services makes Berna stand out from her parents, who no longer continue the Alevi religious tradition, as well as from other young women of her age, who have no avenue to a culture that is as specific as this one. Our thesis is that Alevism becomes a central resource for Berna's identity, with which she can, on the one hand, establish her difference as something positive. On the other hand, it allows her to 
construct a unique identity that serves to establish her independence from her parents, while at the same time gives way to a closer relationship to her cultural background. This differentiates her from her peers in a particular and positive manner, since they get to know culture at best as a mass phenomenon, as pop culture. Berna expresses the significance that Alevism has for her in these terms:

B: that's why I guess it's so important to me to keep my culture and that I don't lose touch with it and that I learn everything about my culture

Berna's turn towards Alevism is not at all associated with negative consequences in relation to the German host society, as is the case for Celile's religious practices for example. Berna's inclusion in the Alevi community does not exclude her from German society; she can combine her membership in both collectives without any problems. This hypothesis is supported by her professional outlook of studying in the field of economics: Berna does not have to take into consideration any obstacles that come about by belonging to the Alevi community.

Both Celile and Berna's parents share an interpretive framework that belongs to modernized society, which includes the opinion that women should learn a profession and be self-reliant. In this sense, they motivate their daughters to pursue a professional career and subsequently support their integration into the German host society. While this path seems open to Berna, Celile's experience of exclusion blocks real possibilities.

\section{Conclusion}

The results of the case studies can be condensed to the hypothesis that the experience of difference becomes a turning point and a core issue in identity formation among Muslim youth. This experience revises those affiliations acquired through childhood and leads to the growth, or rather reinforcement, of relationships with the culture of origin. It (re)establishes apparently clear affiliations through ruptures with significant others (cf. Schiffauer 2002). This process that plays itself out in the triangulation of milieu, peers, and host society sets in motion reflective thinking about cultural background and the (re)appropriation of that background. The interpretive framework of the German host society is already integrated into this reflection as a point of reference. As we have been able to show through the reconstruction of these cases, identity formation among Muslim adolescents takes place in this process of negotiating difference and belonging.

However, these cases also illustrate the boundaries set to the young people within this formative process by their milieu as well as by the German host society. On the one hand, milieu specific patterns of interpretation, its values and norms limit the adolescents' possibilities, because they do not allow adolescents testing their actions and their environment and making further experiences (particularly sexual issues). On the other hand, the German society offers only certain possibilities and refuses others - for instance to be "German" in a 
different way than the majority. At the same time, the adolescents' 'natural' identification with their background culture or religion is repressed, because it is attributed as 'backwards' or 'inferior' in the public discourse. According to our concluding hypothesis, it seems essential for a successful identity formation of young Muslims that their milieu as well as the host society allows and enables them to handle their cultural diversity in a creative way. Then, their cultural heritage and the new options allocated by the German society could provide resources to shape their unique identity. In this way, Muslim adolescents would not have to refer necessarily to their religious roots only to cope with their cultural diversity, but could benefit from the variety of modern life scripts.

\section{References}

Ammerman, Nancy T. (2003), Religious Identities and Religious Institution. In: Dillon, Michele (ed.), Handbook of Sociology of Religion. Cambridge: University Press, pp. 207-224.

Apitzsch, Ursula (2005), Migration und Adoleszenz. In: Kind, Jugend und Gesellschaft, Vol. 50, No.1, pp. 12-18.

Blos, Peter (1995), Adoleszenz. Eine psychoanalytische Interpretation. Stuttgart: Klett (Orig.: On adolescence. New York 1962).

Bourdieu, Pierre (1974), Der Habitus als Vermittlung zwischen Struktur und Praxis. In: ibid. (ed.), Zur Soziologie der symbolischen Formen. Frankfurt/M.: Suhrkamp, pp. 125-158.

Bourdieu, Pierre (1976), Entwurf einer Theorie der Praxis auf der ethnologischen Grundlage der kabylischen Gesellschaft. Frankfurt/M: Suhrkamp.

Erdheim, Mario (1983), Adoleszenz zwischen Familie und Kultur. Ethno-psychoanalytische Überlegungen zur Funktion der Jugend in der Kultur. In: Psychosozial. Vol. 17, pp. 104-116.

Erikson, Erik H. (1970), Jugend und Krise. Die Psychodynamik im sozialen Wandel. Stuttgart: Klett.

Gärtner, Christel (2003), Egotaktiker mit spontanen Solidaritätsverpflichtungen? Zur Wahrnehmung jugendlicher Engagementbereitschaft in der Jugendforschung. In: Große Kracht, Hermann-Josef (ed.), Solidarität institutionalisieren. Arenen, Aufgaben und Akteure christlicher Sozialethik. Beiträge aus dem Institut für Christliche Sozialwissenschaften. Karl Gabriel zum 60. Geburtstag. Vol. 50, Münster: Lit, pp. 97-111.

Giddens, Anthony (1991), Modernity and Self-Identity. Self and Society in the Late Modern Age. Cambridge: Polity Press.

Herbert, Markus / Hans-Georg Ziebertz (2010), Plurale Identität und interkulturelle Kommunikation. In: Ziebertz, Hans-Georg (ed.), Gender in Islam und Christentum. Theoretische und empirische Studien. Berlin: Lit, pp. 111-125.

Jindra, Ines W. / Michael Jindra (2003), Structural ("Objective") Hermeneutics and the Sociology of Religion. In: Piedmont, Ralph / David O. Moberg (ed.), Research in the Social Scientific Study of Religion. Leiden/Boston: Brill, pp.253-275.

Kaya, Asiye (2009), Mutter-Tochter-Beziehungen in der Migration. Biographische Erfahrungen im alevitischen und sunnitischen Kontext, Wiesbaden: VS Verlag für Sozialwissenschaften. 
King, Vera (2002), Die Entstehung des Neuen in der Adoleszenz. Individuation, Generativität und Geschlecht in modernisierten Gesellschaften. Opladen: Leske \& Budrich.

Lehmann, Hartmut (2004), Säkularisierung. Der europäische Sonderweg in Sachen Religion, Bd. 5. Göttingen: Wallstein.

Levitt, Peggy (2009), Roots and Routes: Understanding the Lives of the Second Generation Transnationally. In: Journal of Ethnic and Migration Studies, Vol. 35, No.7, pp. 1225-1242.

Levitt, Peggy / Nadya B. Jaworsky (2007), Transnational Migration Studies: Past Developments and Future Trends. In: Annual Review of Sociology. Vol. 33, pp. 129-156.

Mannitz, Sabine (2006), Die verkannte Integration. Eine Langzeitstudie unter Heranwachsenden aus Immigrantenfamilien, Bielefeld: transcript.

Matthes, Joachim (1992), Auf der Suche nach dem "Religiösen". Reflexionen zu Theorie und Empirie religionssoziologischer Forschung. In: Sociologia Internationalis. No. 30, pp. 129-142.

McLeod, Hugh (2007), The Religious Crisis of the 1960s. Oxford: University Press.

Mead, George Herbert (1962), Mind, Self, and Society from the Standpoint of a Social Behaviorist. Chicago: University Press.

Modood, Tariq (2003), New Forms of Britishness: Post-Immigration Ethnicity and Hybridity in Britain. In: Sackmann, Rosemarie / Bernhard Peters / Thomas Faist (ed.), Identity and Integration. Aldershot: Ashgate Publishing Ltd.

Oevermann, Ulrich (1991), Genetischer Strukturalismus und das sozialwissenschaftliche Problem der Erklärung der Entstehung des Neuen. In: Müller-Doohm, Stefan (ed.), Jenseits der Utopie. Theoriekritik der Gegenwart. Frankfurt/M.: Suhrkamp, pp. 267-336.

Oevermann, Ulrich (1995), Ein Modell der Struktur von Religiosität. Zugleich ein Strukturmodell von Lebenspraxis und von sozialer Zeit. In: Wohlrab-Sahr, Monika (ed.), Biographie und Religion. Zwischen Ritual und Selbstsuche. Frankfurt/M./New York: Campus-Verlag, pp. 27-102.

Oevermann, Ulrich (2000), Die Methode der Fallrekonstruktion in der Grundlagenforschung sowie der klinischen und pädagogischen Praxis. In: Klaus Kraimer (ed.), Die Fallrekonstruktion. Frankfurt/M: Suhrkamp, pp. 58-153.

Oevermann, Ulrich (2003), Strukturelle Religiosität und ihre Ausprägungen unter Bedingungen der vollständigen Säkularisierung des Bewusstseins. In: Gärtner, Christel / Detlef Pollack / Monika Wohlrab-Sahr (ed.), Atheismus und religiöse Indifferenz. Opladen: Leske \& Budrich, pp. 339-387.

Reuter, Astrid (2009), Religion - Identitätsressource von Migranten? Eine religionssoziologische Studie. In: Faber, Richard / Susanne Lanwerd (ed.), Aspekte der Religionswissenschaft. Würzburg: Königshausen \& Neumann, pp. 183-203.

Schiffauer, Werner (2002), Migration und kulturelle Differenz. Studie für das Büro der Ausländerbeauftragten des Senats von Berlin: Mercedes-Druck.

Tiesler, Nina Clara (2006), Muslime in Europa: Religion und Identitätspolitiken unter veränderten gesellschaftlichen Verhältnissen, Berlin/Münster: Lit.

Ziebertz, Hans-Georg / Helene Coester / Andrea Betz (2010), Normierung von Sexualität und Autonomie. Eine qualitative Studie unter christlichen und muslimischen Mädchen. In: Ziebertz, Hans- 
Georg (ed.), Gender in Islam und Christentum. Theoretische und empirische Studien. Berlin: Lit, pp. 207-247.

Ziebertz, Hans-Georg / Chris Hermans / Ulrich Riegel (2010), Interkulturalität, Identität und Religion. In: Ziebertz, Hans-Georg (ed.), Gender in Islam und Christentum. Theoretische und empirische Studien. Berlin: Lit, pp. 79-92. 